Available online at www.macvetrev.mk

\author{
Original Scientific Article
}

\title{
EFFECTS OF EXPERIMENTAL TRYPANOSOMA CONGOLENSE INFECTION ON SPERM MORPHOLOGY IN YANKASA RAMS
}

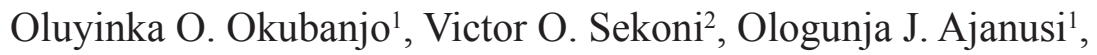 \\ Adewale A. Adeyeye ${ }^{3}$ \\ ${ }^{1}$ Department of Veterinary Parasitology and Entomology, \\ Faculty of Veterinary Medicine, Ahmadu Bello University, Zaria-Nigeria \\ ${ }^{2}$ Department of Veterinary Public Health and Reproduction, College of Veterinary \\ Medicine, Federal University of Agriculture, Abeokuta-Nigeria \\ ${ }^{3}$ Department of Theriogenology and Animal Production, \\ Faculty of Veterinary Medicine, Usmanu Danfodiyo University, Sokoto-Nigeria
}

Received 29 April 2015; Received in revised form 2 July 2015; Accepted 13 July 2015

\begin{abstract}
The objective of the study was to determine the effect of $T$. congolense on the sperm morphology of Yankasa rams (YKR). Nine YKR aged 24-30 months-old were assigned into two groups of 6 infected and 3 uninfected control and were monitored for 7 weeks. The infected group of YKR was each inoculated with $1 \times 10^{6} \mathrm{~T}$. congolense through the jugular vein, while the control group remained uninfected. The entire infected group developed trypanosomosis post infection (pi) characterized by sperm morphological abnormalities in the semen. There were significant $(\mathrm{P}<0.001)$ increases in the mean percentage of acrosomal, head, middle piece and tail abnormalities. Proximal and distal droplets as well detached heads were also significantly $(\mathrm{P}<0.001)$ increased post infection (pi). Acrosomal abnormalities, distal droplet and tail abnormalities increased from week 1 pi till the end of the study, while head abnormalities and detached heads increased from week 2 pi. Middle piece abnormalities and proximal droplets increased from week 3 and 4 pi till the end of the study respectively. The high incidence of morphological defects caused by $T$. congolense is capable of causing infertility from the first week pi thereby making the rams unfit for breeding at the end of the study.
\end{abstract}

Key words: infertility, sperm abnormalities, spermatogenesis, Trypanosoma congolense, Yankasa rams

\section{INTRODUCTION}

Sheep is a major source of animal protein in Nigeria (21), playing an important role in the livelihood of most Nigerians (26). Their distribution is majorly affected by socio-economic and environmental factors, such as availability of feeds, animal traction, marketing systems, cultural preferences and disease (8), which is a major constraint to livestock production in Nigeria (15).

Corresponding author: Dr. Adewale A. Adeyeye, DVM

E-mail address: adewale.adeyeye@udusok.edu.ng

Present address: Department of Theriogenology and Animal Production, Faculty of Veterinary Medicine, Usmanu Danfodiyo University,

Sokoto-Nigeria

Phone: +2348032859940

Copyright: (C) 2015 Okubanjo O.O. This is an open-access article published under the terms of the Creative Commons Attribution License which permits unrestricted use, distribution, and reproduction in any medium, provided the original author and source are credited. Competing Interests: The authors have declared that no competing interests exist

Available Online First: 27 July 2015

http://dx.doi.org/10.14432/j.macvetrev.2015.07.050
Trypanosomosis is an economic and zoonotic disease caused by protozoa of the genus Trypanosoma (20). It affects the cardiovascular, nervous, respiratory, digestive and reproductive systems of the body (12).

In the male reproductive tract, pathological disorders attributed to trypanosomosis include testicular degeneration, scrotal inflammation, penile protrusion, prepucial inflammation, testicular odema, epididymitis and abnormal spermatogenesis $(1,33,34,35)$. In the female, there is abortion, irregular oestrus cycle, cystic degeneration of the ovary, follicular cyst, flaccidity of the uterine horn, decreased conception rate, low birth-weights and neonatal death $(10,13,16,28)$. In addition, pregnant animals infected by trypanosomes may die before or after parturition $(4,6)$.

Trypanosoma congolense has a wide host range $(11,19)$. It is transmitted biologically (17) although mechanical (12) as well as congenital transmissions (14) have been reported. Infection of males with 
T. congolense causes severe testicular degeneration, penile protrusion, haemorrhage, prepucial inflammation, decreased testosterone levels, increased cortisol concentration, depressed pituitary and adrenocortical functions in sheep, cattle and pig $(18,31,35)$. Although Adeyemo et al. (3) studied the pathogenesis of $T$. congolense and T. brucei infections on West African Dwarf ram, while Sekoni (33) the effect of T. vivax on sperm morphology in Yankasa rams, there is no study on the effect of T. congolense on reproduction in Yankasa rams to the best of our knowledge. Aspects of the study involving genital lesions, reaction time, and semen characteristics have been described elsewhere (23, 24). This paper therefore reports on the effect of $T$. congolense on the incidence of sperm morphology of Yankasa rams.

\section{MATERIAL AND METHODS}

The study was carried out at the experimental animal house, Faculty of Veterinary Medicine, Ahmadu BelloUniversity Zaria, Nigeria. Ninemature healthy Yankasa rams from an initial flock of sixteen rams purchased from local markets around the study facility were used. Their age was $24-30$ months old and they were fed on legume hay (harawa), ground nut, maize offal, concentrate $(100 \mathrm{gm} / \mathrm{head} /$ day) multi-mineral nutrient block and fresh pasture. Water was also provided ad libitum throughout the experiment. The animals were acclimatized for 4 months in fly and tick proof pens. Trypanosoma congolense used for this study was obtained from the Nigerian Institute for Trypanosomiasis Research (NITR) Vom, Nigeria. This trypanosome was initially isolated from cattle but inoculated into mice and maintained by continuous passage until use. The study was approved by the ethical board of the Faculty of Veterinary Medicine, Ahmadu Bello University, Zaria and adequate measures were taken to minimize pain or discomfort.

The rams were divided into 2 groups of six infected and three uninfected control. They infected group of six (6) animals were inoculated with $1 \times 10^{6}$ Trypanosoma congolense through the jugular vein. All the rams were closely monitored for clinical signs suggestive of trypanosomosis. Semen was collected weekly from each ram, for seven weeks using electro-ejaculator and evaluated according to the methods of Chemineau and Cagnie (9). Sperm morphological abnormalities were estimated by dilution of semen sample with buffered formal saline and by staining with eosin-nigrosin stain then counting at least 500 sperms per slide as described by Sekoni et al. (29). Data obtained were analyzed 204 using unpaired student $t$-test on SAS computer package. Values of $\mathrm{P}<0.001$ were considered statistically significant.

\section{RESULTS}

The parasites were detected in the infected Yankasa rams within 7-11 days post infection (pi). There was a steady increase in mean acrosomal abnormalities of the infected Yankasa rams from $0.43 \%$ to between $1.66 \%$ and $12.25 \%$ pi. These values were significantly increased $(\mathrm{P}<0.001)$ from week 1 pi compared to the control group, that ranged from $0.33 \%-1.25 \%$ pi (Fig. 1 ).

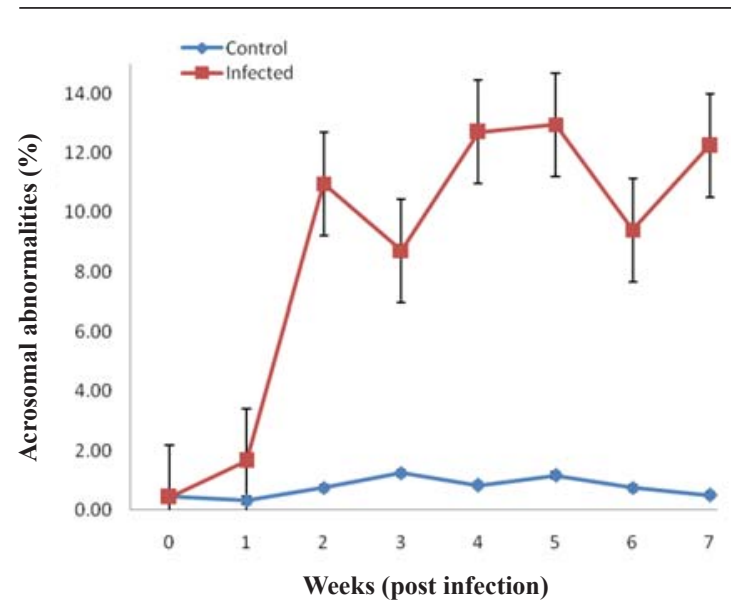

Figure 1. Mean percentage acrosomal abnormalities of Yankasa rams experimentally infected with $T$. congolense

The mean head abnormalities rose from $0.04 \%$ pre-infection to a pi value of $0.88 \%-9.55 \%$ for the infected group, which were significantly $(\mathrm{P}<0.001)$ increased compared to the control group $(0.67 \%$ $1.00 \%$ ) from week 2 pi (Fig. 2).

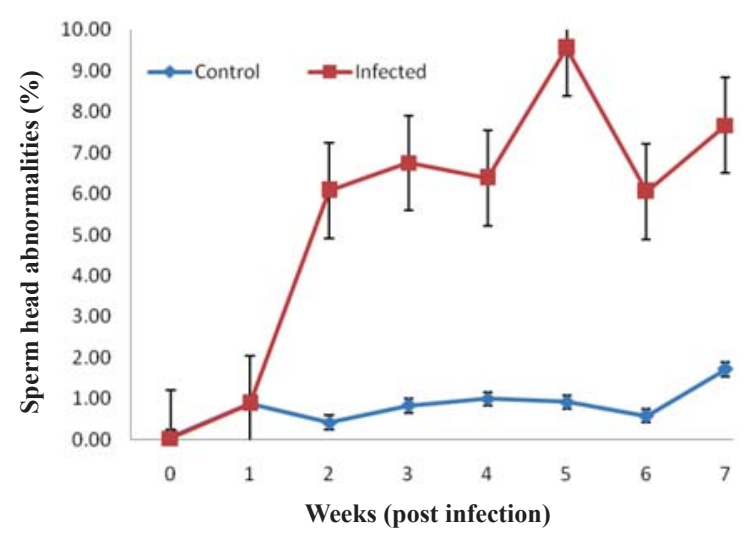

Figure 2. Mean percentage sperm head abnormalities of Yankasa rams experimentally infected with $T$. congolense 


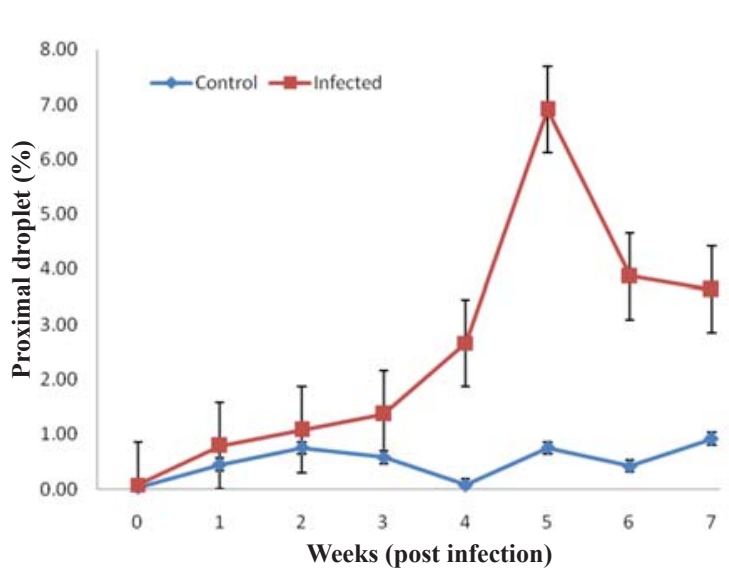

Figure 3. Mean percentage proximal droplet of Yankasa rams experimentally infected with $T$. congolense

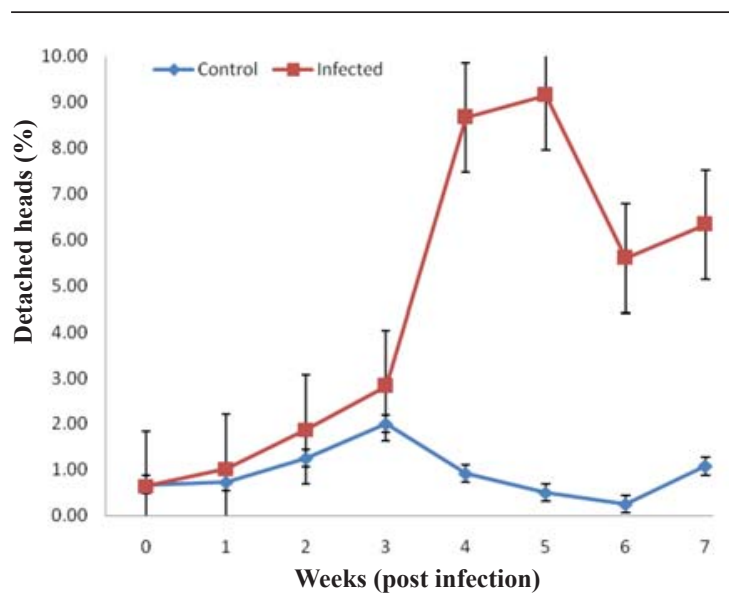

Figure 5. Mean percentage detached heads of Yankasa rams experimentally infected with $T$. congolense

The mean proximal droplet values of infected Yankasa rams $(0.33 \%-6.15 \%)$ were significantly increased $(\mathrm{P}<0.001)$ compared to the control $(0.08 \%$ $-0.92 \%$ ) from week 4 pi till the end of the study (Fig. 3). There was also significant increase $(\mathrm{P}<0.001)$ in the mean distal droplet of the infected group $(0.83 \%-4.33 \%)$ compared to the control group $(0.00 \%-0.42 \%)$ from week 1 pi till the end of the study (Fig. 4). The mean percentage of detached sperm heads of control and infected rams is presented in Figure 5. There was a significant $(\mathrm{P}<0.001)$ increase in the mean detached heads of the infected rams $(1.02 \%-9.15 \%)$ compared to the control $(0.25 \%-2.00 \%)$ from week 2 pi till the end of the study. The middle piece abnormalities of the infected rams (1.98 \% - $22.79 \%)$ were significantly $(\mathrm{P}<0.05)$ increased compared to rams in the control group $(0.08 \%-3.63 \%)$, from week 3 pi till the end of the study (Fig. 6).

Tail abnormalities also significantly $(\mathrm{P}<0.05)$ increased, but from week 1 pi till the end of the study in the infected rams $(13.99 \%-44.75 \%)$ compared

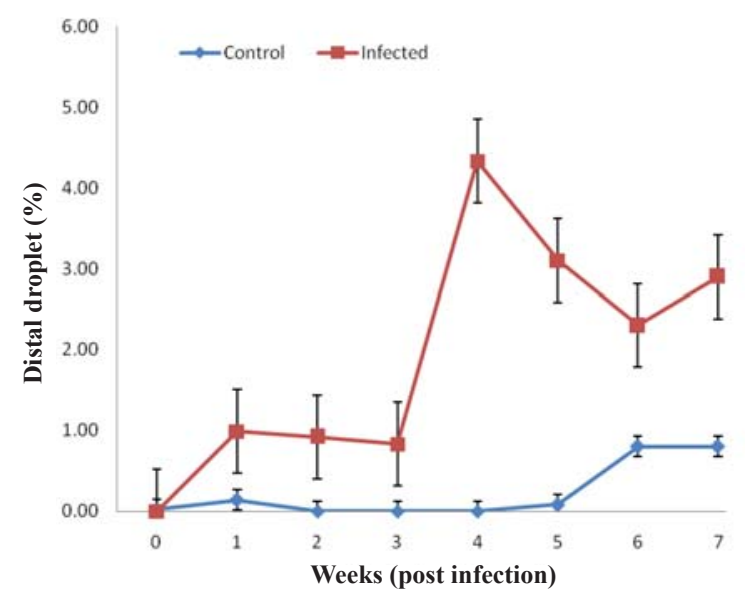

Figure 4. Mean percentage distal droplet of Yankasa rams experimentally infected with $T$. congolense

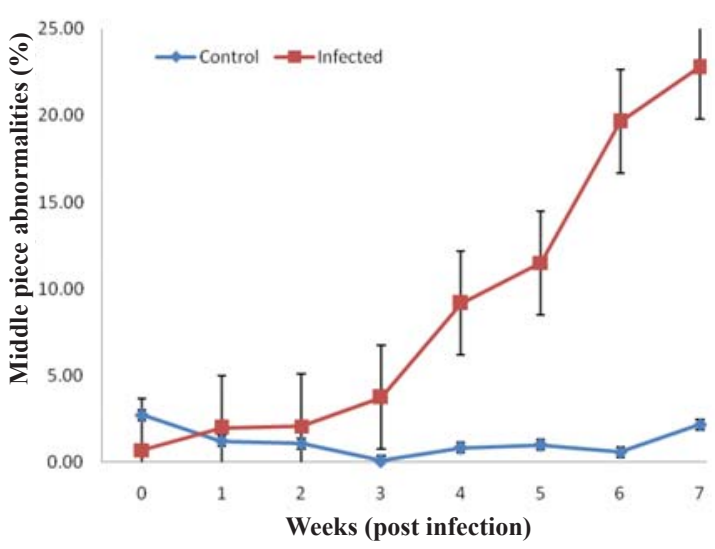

Figure 6. Mean percentage middle piece abnormalities of Yankasa rams experimentally infected with $T$. congolense

to rams in the control group $(6.72 \%-16.72 \%)$ (Fig. 7). Sperm tail abnormalities were more prominent in infected rams than abnormalities associated with the sperm head.

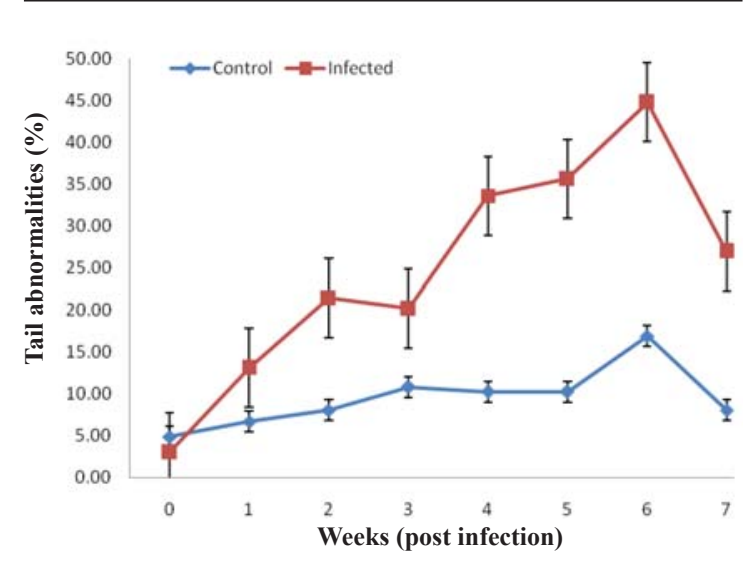

Figure 7. Mean percentage tail abnormalities of Yankasa rams experimentally infected with T. congolense 


\section{DISCUSSION}

The infection of Yankasa rams with T. congolense showed some clinical signs (fluctuating, pyrexia, ruffled hair coat, dullness, weight loss and pallor of the mucous membrane) that have been published in our previous investigations (24).

In this study we demonstrated the adverse effect of $T$. congolense infection on the sperm morphology of Yankasa rams. The morphological abnormalities seen were acrosome abnormalities, sperm head abnormalities, proximal droplet, distal droplet, middle piece abnormalities, detached head and tail abnormalities. Sperm morphology is one of the factors determining semen quality besides sperm motility and concentration (27). The occurrence of sperm morphological abnormalities in the semen of animals is associated with infertility and sterility (30). From the first week of infection, substantial acrosomal, tail and distal droplets defects were observed. This was capable of compromising acrosomal reaction and sperm motility and by extension the fertility of infected animals. Other morphological abnormalities were seen in the second (sperm head and detached head abnormalities); third (middle piece) and fourth (proximal droplet) weeks post infection. However, signs of infertility in the infected rams would have been evident as early as the first week and will continue to increase till the end of the study. This progressive increase in abnormalities for the 7 weeks study period, which is also the duration for a spermatogenic cycle in rams, suggest that $T$. congolense infection in Yankasa rams may not just affect the spermatogenesis in the testicles alone, but also the maturation process at the tail of the epididymis. This is supported by the lesions observed in the epididymis and the testis in our earlier study (23). The sperm morphological abnormalities seen in this study are also similar to those reported by Sekoni (33) in T. vivax infected Yankasa rams where abnormalities were seen from the second week post infection. However, in this study, abnormalities were seen from the first week post infection. The variation in trypanosome specie maybe responsible for this, since its infectivity and pathogenesis depends on the specie and strain of the trypanosome (22). This may suggest that $T$. congolense in more virulent than $T$. vivax in Yankasa rams. Previous studies in bulls have also supported this fact $(32,34)$. Osaer et al. (25) observed minor morphological abnormalities following infection of Djallonke rams with $T$. congolense. They also observed return of sperm morphology to their pre-infection state as the infection progressed in this breed of sheep. This is contrary to the report in this study, which may have been influenced by breed difference. The Djallonke sheep is a West Africa Dwarf sheep found in Gambia and are generally known to be trypanotolerant surviving in tsetse infested areas (7). In contrast, the Yankasa breed used in this study are highly susceptible to trypanosomosis $(2,5,33)$.

\section{CONCLUSION}

The $T$. congolense used in this study is pathogenic to Yankasa rams with substantial percentage of sperm morphological abnormalities. The outcome of this on Yankasa rams in field situation may increase the incidence of infertility which is detrimental to sheep production.

\section{REFERENCES}

1. Adamu, S.; Fatihu, M. Y., Useh, N. M., Mamman, M., Sekoni, V. O., Esievo, K. A. N. (2007). Sequential testicular and epididymal damage in Zebu bulls experimentally infected with Trypanosoma vivax. Veterinary Parasitology, 143(1): 29-34.

http://dx.doi.org/10.1016/j.vetpar.2006.07.022 PMid:16935425

2. Adenowo, T. K, Njoku, C. O., Oyedipe, E. O., Sannusi, A. (2004). Experimental trypanosomiasis in Yankasa ewes: the body weight response. African Journal of Medicine and Medical Sciences, 33(4): 323-326. PMid:15977439

3. Adeyemo, O.; Oyejide, A., Agbedana, O. (1990). Plasma testosterone in Trypanosoma congolense and Trypanosoma brucei infected West African dwarf rams. Animal Reproduction Science, 22, 21-26. http://dx.doi.org/10.1016/0378-4320(90)90034-D

4. Anene, B. M., Omamegbe, J. O. (1984). Abortion associated with Trypanosoma brucei infection in an Alsatian bitch: A case report. Tropical Veterinarian, 2, 211-213.

5. Audu, P. A., Esievo, K. A. N., Mohammed, G., Ajanusi, O. J. (1999). Studies on infectivity and pathogenicity of an isolate of Trypanosoma evansi in Yankasa sheep. Veterinary Parasitology, 86, 185-190. http://dx.doi.org/10.1016/S0304-4017(99)00141-7

6. Bawa, E. K., Sekoni. V. O., Olorunju. S. A. S., Uza, D. V., Ogwu, D., Oyedipe, E. O. (2005). Comparative clinical observations on Trypanosoma vivax infected pregnant Yankasa and West African Dwarf ewes. Journal of Animal and Veterinary Advances, 4 (7): 630-636.

7. Bengaly Z., Clausen, P. H., Boly, H., Kanwe, A., Duvallet G. (1993). Comparison of experimental trypanosomiasis in various breeds of small ruminants in Burkina Faso. Revue d'Elevage et de Medcine Veterinaire des Pays Tropicaux, 46(4): 563-570. PMid:7915427 
Effects of Trypanosoma congolense infection on sperm morphology in rams

8. Blench, R. M. (1999). Traditional livestock breeds: geographical distribution and dynamics in relation to the ecology of West Africa. Retrieved November, 28, 2010 from http://www.odi.org.uk/resources/download/2041.pdf.

9. Chemineau, P., Cagnie, Y. (1991). Training manual on artificial insemination in sheep and goats. FAO Animal Production and Health Paper: 83.

10. Dalal, S. M., Amer, H. A., Rwaida, M. R. (2008). Pathological and some biochemical studies on pregnant ewes experimentally infected with Trypanosoma evansi. Egyptian Journal Comparative Pathology and Clinical Pathology, 21, 372- 400.

11. Desquesnes, M. (2004). Livestock Trypanosomoses and their Vectors in Latin America (English translation). Published by World Organization for Animal Health (OIE). PP. 8-19.

12. Desquesnes, M., Dia, M. L. (2003). Mechanical transmission of Trypanosoma congolense in cattle by the African tabanid Atylotus agrestis. Experimental Parasitology, 105: 226-231.

http://dx.doi.org/10.1016/j.exppara.2003.12.014 PMid:14990316

13. Faye, D., Sulon, J., Kane, Y., Beckers, J. F., Leak, S., Kaboret, Y., Sousa, N. M., Losson, B., Geerts, S. (2004). Effects of an experimental Trypanosoma congolense infection on the reproductive performance of West African Dwarf goats. Theriogenology, 62: 1438-1451.

http://dx.doi.org/10.1016/j.theriogenology.2004.02.007 PMid:15451252

14. Griffin, L. (1983). Congenital transmission of Trypanosoma congolense in mice. Journal of Comparative Pathology, 93(3): 489-492. http://dx.doi.org/10.1016/0021-9975(83)90036-1

15. Lamorde, A. G. (1996). The role of veterinarians in a developing economy. Nigerian Veterinary Journal (Special Edition), 1(1): 106-111.

16. Leigh, O. O., Fayemi, O. E. (2013). The effect of experimental Trypanosoma brucei infection on hormonal changes during the oestrous cycle, pregnancy and pregnancy outcome in West Africa Dwarf does. Wayamba Journal of Animal Science, ID 1365263763.

17. Mbaya, A. W., Kumshe, H., Nwosu, C. O. (2012). The mechanisms of anaemia in trypanosomosis: A Review. In: Anemia, (D. Silverberg editor.). Published by InTech. pp. 276.

http://dx.doi.org/10.5772/29530

18. Mutayoba, B. M., Eckersall, P. D., Seely, C., Gray, C. E., Cestnik, V., Jeffcoate, I. A., Holmes, P. H. (1995). Effects of Trypanosoma congolense on pituitary and adrenocortical function in sheep: responses to exogenous corticotrophin-releasing hormone. Research in Veterinary Science, 58, 180-185. http://dx.doi.org/10.1016/0034-5288(95)90074-8
19. Office of the International Epizootic (OIE) (2009). Trypanosomosis (Tsetse-transmitted). Retrieved from www.oie.int/fileadmin/...in.../TRYPANO_TSETSE_ FINAL.pdf.

20. Office of the International Epizootic (OIE) (2013). Trypanosomosis - tsetse transmitted. In: OIE Terrestrial Manual. pp. 1-11.

21. Opasina B.A., David-West K.B. (1987). Position paper on sheep and goat production in Nigeria. In: Proceedings of an FAO seminar on Sheep and goat meat production in the humid tropics of West Africa held in Yamoussoukro, Côte d'lvoire. PMid:3424454

22. Ogunsanmi, A. O., Akpavie, S. O., Anosa, V. O. (1994). Haematology changes in ewes experimentally infected with Trypanosoma brucei. Revue d"Elevage et de medicine Veterinaire des pays Tropicaux, 47(1): 53-57.

23. Okubanjo, O. O.; Sekoni, V. O.; Ajanusi, O. J., Nok, A. J., Adeyeye, A. A. (2014). Testicular and epididymal pathology in Yankasa rams experimentally infected with Trypanosoma congolense. Asian Pacific Journal of Tropical Disease, 4(3): 185-189. http://dx.doi.org/10.1016/S2222-1808(14)60502-8

24. Okubanjo, O. O., Sekoni, V. O., Ajanusi, O. J., Adeyeye, A. A. (2014). Semen characteristics and reaction time of yankasa rams experimentally infected with Trypanosoma congolense. Global Veterinaria, 13 (3): 297-301.

25. Osaer S., Goossens, B., Sauveroche, B., Dempfle, L. (1997). Evaluation of the semen quality and reproductive performance of trypanotolerant Djallonké rams following an artificial infection with Trypanosoma congolense. Small Ruminant Research, 24(3): 213-222.

http://dx.doi.org/10.1016/S0921-4488(96)00944-3

26. Otchere E. O. (1986). Small ruminant production in tropical Africa. In: Proceedings an FAO expert consultation held in Sofia, Bulgaria, 8-12 July 1985. Paper 58.

27. Podstawski Z., Kosiniak-Kamysz K., Bittmar A. (2007). Relationship between some enzymes activity, sperm morphology and stallion semen quality. Zootehnie şi Biotehnologii, 40(1): 152-156.

28. Rodrigues, C. M. F., Olinda, R. G., Silvaa, T. M. F., Valea, R. G., Da Silvaa, A. E., Limaa, G. L., Garciab, H. A., Teixeirab, M. M. G., Batista, J. S. (2013). Follicular degeneration in the ovaries of goats experimentally infected with Trypanosoma vivax from the Brazilian semi-arid region. Veterinary Parasitology, 191, 146-153.

http://dx.doi.org/10.1016/j.vetpar.2012.08.001 PMid:22921989 
29. Sekoni, V. O.; Gustafsson, B. K., Mather, E. C. (1981). Influence of wet fixation staining techniques and storage time on bull sperm morphology. Nordisk Veterinaer Medicin, 33, 161-166. PMid:6172775

30. Sekoni, V. O., Gustafsson, B. K. (1987). Seasonal variations in the incidence of sperm morphological abnormalities in dairy bulls regularly used for artificial insemination. British Veterinary Journal, 43, 312-317. http://dx.doi.org/10.1016/0007-1935(87)90064-9

31. Sekoni, V. O.; Njoku, C. O.; Kumi-Diaka, J., Saror, D. I . (1990a). Pathological changes in male genitalia of cattle infected with Trypanosoma vivax and Trypanosoma congolense. British Veterinary Journal, 146, 175-180.

http://dx.doi.org/10.1016/0007-1935(90)90011-Q

32. Sekoni V. O., Saror D. I., Njoku C. O., Kumi-Diaka J. (1990b). Elevation of morphological abnormalities of spermatozoa in the semen of Zebu bulls consequent to Trypanosoma vivax and Trypanosoma congolense infections. Theriogenology, 33(4): 925-936.

http://dx.doi.org/10.1016/0093-691X(90)90827-G
33. Sekoni V. O. (1993). Elevated sperm morphological abnormalities of Yankasa rams consequent to Trypanosoma vivax infection. Animal Reproduction Sciences, 31(3-4): 243-248.

http://dx.doi.org/10.1016/0378-4320(93)90009-G

34. Sekoni, V. O., Rekwot, P. I., Bawa, E. K. (2004). Effects of Trypanosoma vivax and Trypanosoma congolense infections on the reaction time and semen characteristics of Zebu (Bunaji) x Friesian crossbred bulls. Theriogenology, 61, 55-62. http://dx.doi.org/10.1016/S0093-691X(03)00183-3

35. Victor I.; Sackey A. K. B., Natala A. J. (2012). Penile protrusion with hemorrhages and prepucial inflammation in pigs experimentally infected with Trypanosoma congolense. Journal of Animal Production Advances, 2(6): 297-302.

Please cite this article as: Okubanjo O.O., Sekoni V. O., Ajanusi O.J., Adeyeye A.A. Effects of experimental Trypanosoma congolense infection on sperm morphology in Yankasa rams. Mac Vet Rev 2015; 38 (2): 203-208. http://dx.doi.org/10.14432/j.macvetrev.2015.07.050 